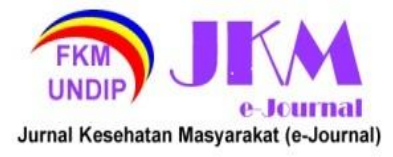

JURNAL KESEHATAN MASYARAKAT (e-Journal)

Volume 10, Nomor 1, Januari 2022

ISSN: 2715-5617 / e-ISSN: 2356-3346

http://ejournal3.undip.ac.id/index.php/jkm

\title{
SURVEI KESADARAN MENTAL MAHASISWA UPN VETERAN YOGYAKARTA DI ERA DIGITAL DAN COVID-19
}

\author{
Adara Bintang Nugroho ${ }^{1 *}$, Hanafiah Beno Al Asri ${ }^{1}$, Ardhia Ajeng Pramesti ${ }^{1}$ \\ ${ }^{1}$ Program Studi Ilmu Komunikasi, Fakultas Ilmu Sosial dan Politik, \\ Universitas Pembangunan Nasional 'Veteran' Yogyakarta \\ *Corresponding author: a.bintangnugroho@gmail.com
}

\begin{abstract}
In Indonesia, the Basic Health Research Data (Riskesdas) 2018 shows the prevalence of emotional mental disorders as indicated by symptoms of depression and anxiety for ages 15 years and over reaches around $6.1 \%$ of the total population of Indonesia or the equivalent of 11 million people. This number has the potential to continue to increase, because people's lives have changed due to the Covid-19 pandemic. Mental health is an issue that cannot be ignored. Changes in people's behavior that have become the new normal such as work from home, study from home and even a number of religious activities have also switched to using live streaming. Thus, the house becomes the center of activity of a family which has the potential to cause mental health disorders. This study aims to find out how students who are running online lectures are aware of mental health problems. The research method was conducted by survey method with random sampling technique. The results of the research show that there is a tendency for respondents to self-diagnose due to incomplete understanding of mental health issues. Therefore, it is hoped that the service strategy for improving the quality of mental health at UPN "Veteran" Yogyakarta can be realized and internalized into the
\end{abstract} education curriculum.

Keywords: mental health, Covid-19, online study

\section{PENDAHULUAN}

Sebagaimana lazimnya negara berkembang, Indonesia mulai tumbuh menjadi negara yang peduli dan sadar akan pentingnya pendidikan. Berbagai upaya dilakukan untuk memenuhi hak masyarakatnya, mulai dari ketersediaan perguruan tinggi yang memadai, hingga berbagai macam beasiswa dan bantuan dari pemerintah maupun organisasi nonprofit. Pada 2017, berdasarkan data Kementerian Riset Teknologi dan Perguruan Tinggi (Ristekdikti), jumlah unit perguruan tinggi yang terdaftar mencapai 4.504 unit (1). Dilihat dari wilayahnya, dengan total 2,1 juta mahasiswa baru, sebanyak 53\% menempuh pendidikan di Pulau Jawa (2). Yogyakarta yang dikenal sebagai kota pelajar pun memiliki setidaknya 101.372 mahasiswa baru.

Semakin berkembangnya dunia pendidikan sejatinya harus dibersamai dengan meningkatnya kesehatan para penuntut ilmu. Terutama dalam perihal kesehatan mental. Kesehatan mental atau jiwa menurut Undang - undang Nomor 18 Tahun 2014 tentang Kesehatan Jiwa merupakan kondisi dimana seseorang dapat berkembang secara fisik, mental, spiritual, dan sosial sehingga individu tersebut menyadari kemampuan sendiri, dapat mengatasi tekanan, dapat bekerja secara produktif, dan mampu memberikan kontribusi untuk komunitasnya. Praktis, kesehatan mental juga mempengaruhi aktivitas fisik dalam kehidupan sehari-hari, termasuk pada kegiatan menuntut ilmu.

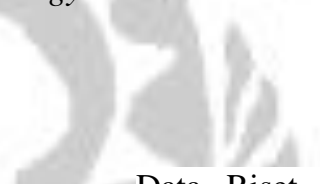

Data Riset Kesehatan Dasar (Riskesdas) 2018 menunjukkan prevalensi gangguan mental emosional yang ditunjukkan dengan gejala-gejala depresi dan kecemasan untuk usia 15 tahun ke atas mencapai sekitar $6,1 \%$ dari jumlah penduduk Indonesia atau setara dengan 11 juta orang. Penduduk berusia 15-24 tahun memiliki persentase depresi sebesar $6,2 \%$. Depresi berat akan menyebabkan kecenderungan bagi penderitanya menyakiti diri sendiri (self harm) hingga bunuh diri. Sebesar 80 90\% kasus bunuh diri merupakan akibat dari depresi dan kecemasan. Kasus bunuh diri di Indonesia bisa mencapai 10.000 atau setara dengan setiap satu jam terdapat kasus bunuh diri. Menurut ahli suicidologists, sebesar 6,9\% mahasiswa mempunyai niatan untuk bunuh diri sedangkan 3\% lain pernah melakukan percobaan bunuh diri.

Guna menjawab isu kesehatan mental yang terjadi, beberapa perguruan tinggi di Indonesia sudah menyediakan layanan kesehatan mental seperti unit konsultasi psikologi bagi mahasiswanya. Terkhusus di kota pelajar, Universitas Gadjah Mada merupakan perguruan tinggi yang sudah menyediakan layanan tersebut bagi para mahasiswa. Tidak dapat dipungkiri, bahwa masih banyak perguruan tinggi negeri lain di Yogyakarta yang belum memberikan fasilitas tersebut kepada mahasiswanya. Salah satunya yakni Universitas Pembangunan Nasional Veteran Yogyakarta. 


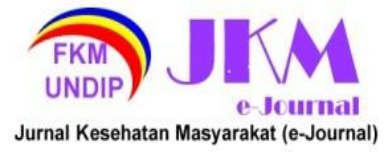

Data di atas cukup untuk membuktikan masalah kesehatan mental di Indonesia yang pada faktanya, diderita oleh masyarakat usia produktif termasuk mahasiswa, belum mendapat perhatian yang memadai. Belum cukup dengan hal ini, Indonesia bahkan dunia harus melewati masa yang cukup sulit yaitu pandemi COVID-19. Virus Corona atau Severe Acute Respiratory Syndrome Coronavirus 2 (SARS$\mathrm{CoV}-2$ ) adalah virus yang menyerang sistem pernapasan. Penyakit karena infeksi virus ini disebut COVID-19. Virus Corona bisa menyebabkan gangguan pada sistem pernapasan, pneumonia akut, sampai kematian. Virus ini bisa menyerang siapa saja, baik bayi, anak-anak, orang dewasa, lansia, ibu hamil, maupun ibu menyusui. Infeksi virus ini disebut COVID-19 dan pertama kali ditemukan di kota Wuhan, Cina, pada akhir Desember 2019.

Virus ini menular dengan cepat dan telah menyebar ke wilayah lain di Cina dan ke beberapa negara, termasuk Indonesia. Grafik kasus virus corona secara global masih terus mengalami peningkatan. Hingga Senin 28 Desember 2020 berdasarkan data Worldometers, total kasus infeksi virus corona di seluruh dunia telah mencapai 81.118.606 kasus. Dari jumlah itu, sebanyak 1.771 .342 orang meninggal dunia, dan 57.273.250 orang dinyatakan sembuh. Tentu tidak ada yang menyangka sebelumnya akan ada virus COVID-19 yang mengharuskan setiap orang untuk berdiam diri di rumah dan tidak bepergian kemana-mana untuk menekan angka penularan virus.

Banyak remaja kehilangan beberapa momen besar di kehidupan mereka karena semua hal harus dilakukan di dalam rumah dan bergantung pada teknologi komunikasi yang ada. Para remaja menghadapi situasi baru ini bukan tidak hanya dengan kecewa, namun juga kecemasan dan perasaan terisolasi yang membebani, serta banyaknya perubahan dalam hidup akibat wabah yang terjadi sangat cepat. Menurut analisis data yang disampaikan Unicef, sebanyak 99 persen anak-anak dan remaja di bawah 18 tahun di seluruh dunia (2,34 miliar) tinggal di salah satu dari 186 negara dengan beberapa bentuk pembatasan gerakan yang berlaku karena COVID-19. Sebanyak 60 persen anak tinggal di salah satu dari 82 negara dengan lockdown penuh (7 persen) atau sebagian (53 persen) - yang jumlahnya mencakup 1,4 miliar jiwa muda.

Didominasi dengan kegiatan di dalam rumah sama dengan remaja mendapatkan salah satu hiburan melalui media sosial. Data pengguna media sosial di Indonesia pada tahun 2020 menunjukkan bahwa usia 18-24 tahun berada di urutan kedua paling banyak menggunakan media sosial. Rinciannya, pengguna laki-laki dan perempuan masing-masing sebanyak
$16,1 \%$ dan $14,2 \%$. Peringkat pertama terbanyak adalah pengguna berusia 25-34 tahun (Statista, 2019). Tidak dapat dipungkiri bahwa media sosial memang memberikan efek positif pada anak-anak dan remaja, baik dengan mengajarkan keterampilan sosial, memperkuat hubungan, maupun hanya bersenangsenang. Namun, penggunaan terus-menerus dari platform ini juga dapat memberikan dampak negatif, terutama pada kesehatan mental dan kesejahteraan pengguna muda.

Menurut data survei Global Health Data Exchange 2017, ada 27,3 juta orang di Indonesia mengalami masalah kesehatan kejiwaan. Artinya, satu dari sepuluh orang di negara ini mengidap gangguan kesehatan jiwa. Untuk data kesehatan mental remaja di Indonesia sendiri pada 2018, terdapat sebanyak 9,8\% merupakan prevalensi gangguan mental emosional dengan gejala depresi dan kecemasan untuk remaja berumur $>15$ tahun, meningkat dibandingkan pada 2013, hanya 6\% untuk prevalensi gangguan mental emosional dengan gejala depresi dan kecemasan untuk remaja berumur $>15$ tahun. Sedangkan untuk prevalensi gangguan jiwa berat seperti skizofrenia pada 2013 mencapai 1,2 per seribu orang penduduk.

Menurut Priyoto (2014), teori Health Belief Model memiliki 5 hal yang dipengaruhi modifying variable sehingga dapat terbentuk likelihood of behaviour. Kelima hal tersebut meliputi: pertama, perceived susceptibility atau kerentanan, yaitu salah satu persepsi yang lebih kuat lansia dengan diabetes melitus dalam mendorong orang untuk mengadopsi perilaku sehat; kedua, perceived severity berkaitan dengan keyakinan/kepercayaan mahasiswa tentang kesehatan mental tentang keseriusan atau keparahan penyakit; ketiga, perceived benefit berkaitan dengan manfaat yang akan dirasakan jika mengadopsi perilaku yang dianjurkan; keempat, perceived barrier berhubungan dengan proses evaluasi mahasiswa dengan kesehatan mental atas hambatan yang dihadapi untuk mengadopsi perilaku baru. Kelima cues to action atau isyarat untuk bertindak adalah peristiwaperistiwa, orang atau hal-hal yang menggerakkan orang untuk mengubah perilaku mahasiswa dengan kesehatan mental. Menilik dari paparan data di atas, penulis tertarik untuk membahas isu kesehatan mental di UPN "VETERAN" Yogyakarta Fakultas Ilmu Sosial dan Ilmu Politik. Faktor pertama mengenai alasan penulis tertarik membahas isu ini adalah karena data menunjukkan bahwa masyarakat usia lebih dari 15 tahun banyak mengalami gangguan mental. Hal tersebut mengindikasikan bahwa mahasiswa bisa termasuk ke dalam data masyarakat yang banyak 


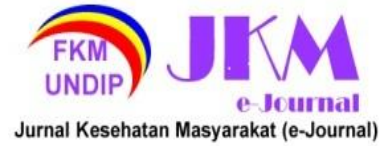

mengalami gangguan kesehatan mental. Faktor kedua pendukung penulis melakukan penelitian adalah karena tidak adanya fasilitas konseling atau bagian psikologi yang difasilitasi oleh kampus UPN "VETERAN" Yogyakarta Fakultas Ilmu Sosial dan Ilmu Politik. Sebagaimana mestinya, universitas seharusnya menyediakan wadah atau fasilitas dalam rangka mengontrol dan menjaga kesehatan psikis mahasiswanya. Faktor ketiga atau yang terakhir yaitu dengan semakin berkembangnya teknologi komunikasi yang seharusnya semakin memudahkan masyarakat untuk mendapatkan informasi atau penanganan profesional tentang kesehatan mental namun pada titik tertentu justru dapat membuat penafsiran yang salah sehingga tingkat kesadaran akan pentingnya kesehatan mental masih harus dimatangkan.

\section{METODE PENELITIAN}

Jenis penelitian ini adalah kuantitatif dengan metode survei analitik dan pengumpulan data diambil dengan menggunakan metode skala likert. Sampel dalam penelitian ini diambil dengan menggunakan teknik sampling Random Sampling dengan jumlah sampel 160 mahasiswa aktif UPN "Veteran" Yogyakarta Jurusan Ilmu Komunikasi angakatan 2020. Penelitian ini menggunakan teori Health Belief Model dengan memasukan variabel demografi, keyakinan kerentanan, keyakinan keseriusan, kepedulian, keyakinan manfaat, keyakinan hambatan, isyarat bertindak.

\section{HASIL DAN PEMBAHASAN \\ Profil Responden}

Responden dari penelitian ini adalah mahasiswa UPN Veteran Yogyakarta, Program Studi Ilmu Komunikasi dan Hubungan Masyarakat angkatan 2020 dengan rentang usia 17-21 tahun. Penulis memilih angkatan 2020 berdasarkan fakta bahwa mereka mengalami pembelajaran online sejak awal kuliah mereka dimulai. Maka dari itu, interaksi mereka terhadap dunia digital cenderung tinggi. Hasil dari survei yang kami lakukan terbagi menjadi tiga bagian utama, berikut penjelasannya:

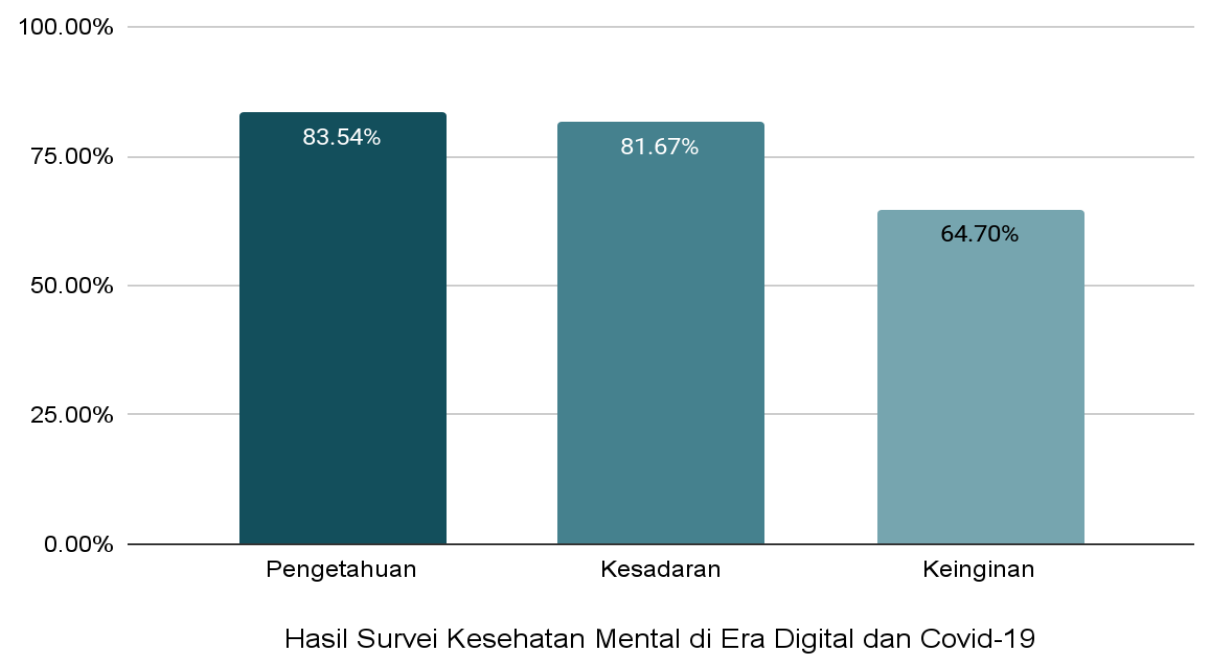

\section{Tahap Pengetahuan}

Pada tahap ini, responden menjawab pertanyaan-pertanyaan seputar pengetahuan mereka akan isu kesehatan mental di lingkungannya dan di media sosial. Pengetahuan terhadap adanya isu kesehatan mental cukup tinggi (83.54\%). Responden yang sangat setuju bahwa dirinya tahu akan adanya isu kesehatan mental sebanyak $66.7 \%$. Dan sebanyak $62.5 \%$ sangat setuju bahwa dirinya mengetahui isu kesehatan mental mulai banyak dibicarakan di media sosial. Responden sebanyak $70.8 \%$ sangat setuju bahwa dirinya mengetahui gangguan kesehatan mental banyak berdampak pada mahasiswa, namun hanya sebanyak $29.2 \%$ saja yang sangat setuju dirinya mengetahui jika di lingkungannya ada yang mengalami gangguan kesehatan mental. Sementara itu, hanya sebanyak $20.8 \%$ responden yang mengetahui bahwa di UPN "Veteran" Yogyakarta belum menyediakan fasilitas konseling kesehatan mental. Hal tersebut menunjukkan bahwa kesadaran responden terhadap isu kesehatan mental sudah cukup baik, namun masih perlu ada dukungan dari universitas untuk menyempurnakannya. 


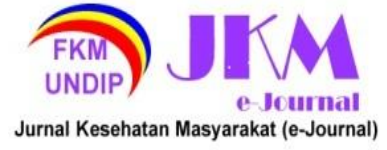

\section{Tahap Kesadaran}

Pada tahap ini, responden menjawab pertanyaan-pertanyaan seputar kesadaran mereka akan isu kesehatan mental di lingkungannya dan di media sosial. Kesadaran responden terhadap adanya isu kesehatan mental masih cukup tinggi $(81.67 \%)$, walaupun mengalami penurunan dari tahap pengetahuan. Tingkat kepercayaan responden bahwa masalah kesehatan mental adalah masalah yang nyata cukup tinggi, yaitu sebanyak $89.6 \%$ responden menjawab sangat setuju. Sebanyak 20.8\% responden menjawab bahwa dirinya pernah mengalami permasalahan kesehatan mental, terlepas apakah mereka sudah memeriksakan diri kepada ahli atau belum. Meski demikian, sebanyak $37.5 \%$ responden mengaku sering merasa stres dengan keadaan. Tentu terdapat banyak faktor yang mempengaruhi hal tersebut. $33.3 \%$ responden merasa tegang, cemas, atau khawatir akhir-akhir ini. Di masa pandemi Covid-19 ini, sebanyak $79.2 \%$ responden menganggap bahwa kesadaran mental adalah isu yang sangat penting.

\section{Tahap Ingin}

Pada tahap ini, responden menjawab pertanyaan-pertanyaan seputar keinginan mereka atau tindakan lebih lanjut akan isu kesehatan mental di lingkungannya dan di media sosial. Keinginan untuk menindaklanjuti isu kesehatan mental cukup rendah (64.7\%). Hal ini dapat dilihat dari $83.3 \%$ responden yang menjawab tidak pernah mengunjungi psikolog untuk memeriksakan kesehatan mentalnya, sehingga sebanyak $62.5 \%$ responden tidak pernah menyarankan psikolog atau psikiater tertentu kepada orang lain. Namun, sebanyak $83.3 \%$ responden setuju dirinya sangat ingin lebih banyak orang yang memahami apa itu isu kesehatan mental. Sayangnya hal ini berbanding terbalik dengan aksi responden yang hanya sebanyak $25 \%$ saja pernah ikut menyebarluaskan kampanye kesehatan mental di media sosial. Namun dengan semakin maraknya isu kesehatan mental, keinginan responden untuk UPN "Veteran" Yogyakarta dalam memberikan fasilitas konseling kesehatan mental bagi civitas akademikanya cukup tinggi yaitu sebanyak $77.1 \%$.

Kehadiran media sosial sebagai sarana untuk meningkatkan pengetahuan dan kesadaran juga tak jarang menjadi pemicu seseorang melakukan self diagnose atau diagnosa sendiri. Hal tersebut dapat dipicu salah satunya oleh kurangnya pemahaman yang tuntas akan suatu isu, dalam hal ini adalah kesehatan mental. Di sisi lain, seseorang juga dapat mengalami gangguan kesehatan mental tanpa ia sadari karena kurangnya informasi tadi. Maka dari itu, media sosial diharapkan menjadi alat pemberi informasi yang tuntas dan jelas kepada khalayak agar kedua hal tersebut tidak terjadi. Berdasarkan data dari survei yang kami lakukan, ada kecenderungan responden melakukan self diagnose. Sebanyak $83.3 \%$ responden mengaku tidak pernah berkonsultasi dengan psikolog, namun $20.8 \%$ responden menjawab pernah mengalami masalah kesehatan mental. Sementara itu keinginan untuk menindak lanjuti isu kesehatan mental cukup rendah yaitu sebanyak $64.7 \%$, hal ini cukup berbanding terbalik dengan pengetahuan mereka yang cukup tinggi.

\section{KESIMPULAN}

Penggunaan media sosial menjadi hal yang sangat umum terlebih pada Generasi $\mathrm{Z}$ dan masa pandemi COVID-19 yang mengaharuskan masyarakat membatasi kegaitan di luar rumah. Media sosial tentu memudahkan masyarakat dalam berbagai aspek, salah satunya dalam mencari informasi tentang isu kesehatan mental. Namun berdasarkan hasil survey yang peneliti buat tentang kesadaran mental mahasiswa UPN Veteran Yogyakarta di era digital dan COVID-19, hasil menunjukkan ada kecenderungan responden melakukan selfdiagnose yang dikarenakan pemahaman akan isu kesehatan mental yang tidak tuntas. Maka dari itu diharapkan strategi layanan peningkatan kualitas kesehatan mental di UPN "Veteran" Yogyakarta dapat direalisasikan dan diinternalisasi ke dalam kurikulum pendidikan. Tidak lupa juga pelaksanaan konseling kesehatan mental dapat dilaksanakan kapan saja dan di mana saja selama jadwal dan persyaratan yang berlaku jelas, sehingga mahasiswa dapat melakukan konseling dengan nyaman.

\section{DAFTAR PUSTAKA}

1. egsaugm. (2020, november 27). Darurat Kesehatan Mental bagi Remaja. Retrieved from EGSAUGM:

https://egsa.geo.ugm.ac.id/2020/11/27/daruratkesehatan-mental-bagi-remaja/

2. indonesiabaik.id. (2021, january 7). indonesiabaik. Retrieved from Perhatikan Kesehatan Mental Remaja Saat Pandemi COVID19: http://indonesiabaik.id/infografis/perhatikankesehatan-mental-remaja-saat-pandemi-covid-19

3. Kementerian Riset Teknologi Dan Pendidikan Tinggi. (2017, mei 5). databoks. Retrieved from berapa jumlah perguruan tinggi di indonesia: https://databoks.katadata.co.id/datapublish/2017/ 


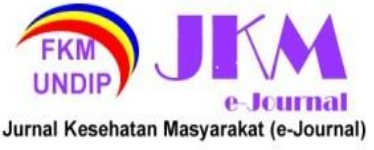

05/05/berapa-jumlah-perguruan-tinggi-diindonesia

4. kementrian kesehatan masyarakat. (2018, maret 3). kesmas.kesmas. Retrieved from Hasil Utama RISKESDAS

https://kesmas.kemkes.go.id/assets/upload/dir_5 19d41d8cd98f00/files/Hasil-riskesdas-

2018_1274.pdf

5. kementrian kesehatan republik indonesia. (2021, mei 3). Virus Corona. Retrieved from alodokter: https://www.alodokter.com/virus-corona

6. Kementrian riset dan teknologi. (2021, februari 11). Kemendikbud Buka KIP Kuliah 2021, Berapa Jumlah Mahasiswa Baru di Indonesia. Retrieved from databoks: https://databoks.katadata.co.id/datapublish/2021/ 02/11/kemendikbud-buka-kip-kuliah-2021berapa-jumlah-mahasiswa-baru-di-indonesia

7. Priyoto. (2014). Teori Sikap dan Perilaku dalam Kesehatan Dilengkapi dengan Contoh Kuesioner. Yogyakarta: Nuha Medika.

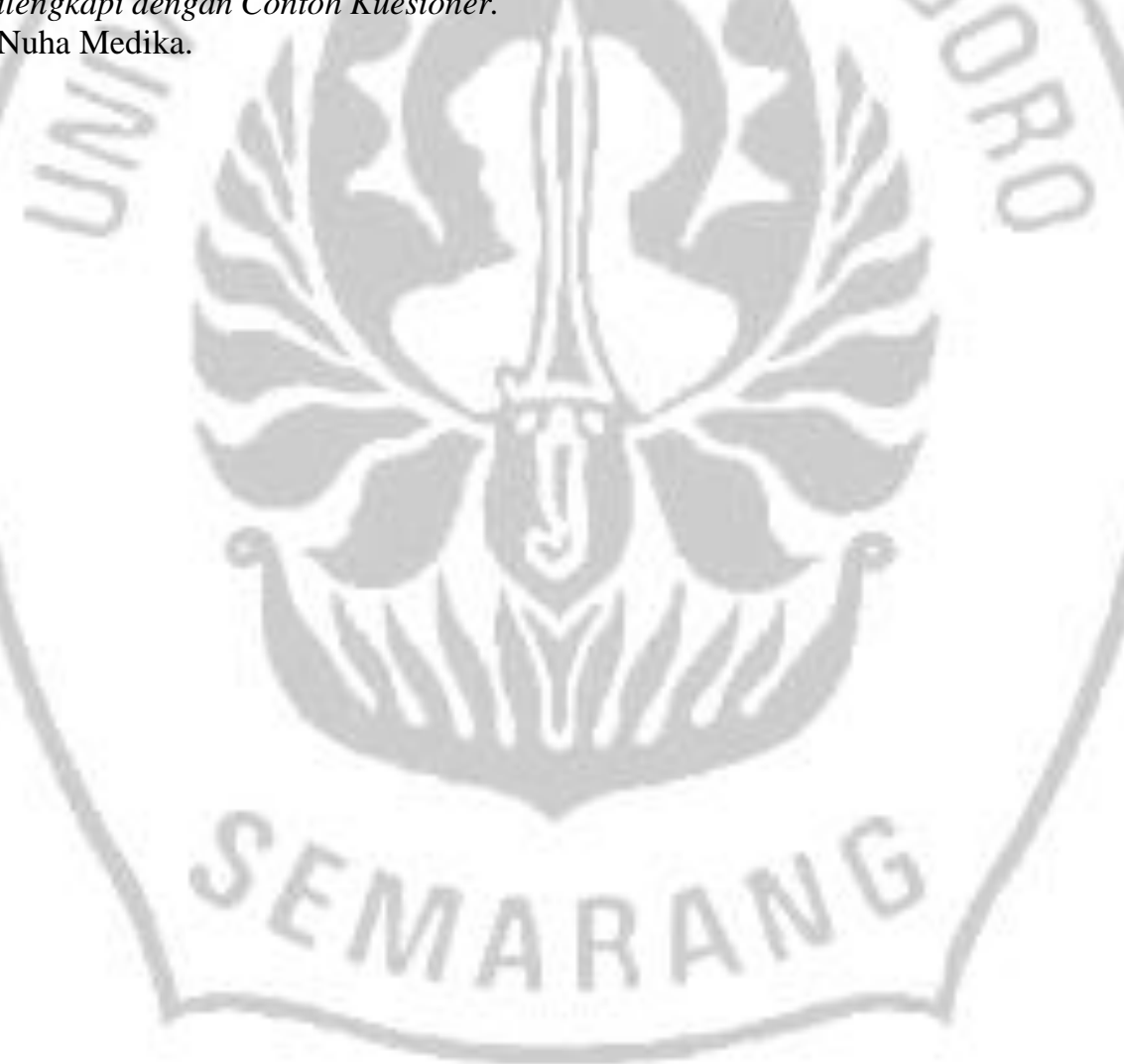

